\title{
Increasing Competence Principal Through "on the Job Learning" on Public High School in Banda Aceh City
}

\author{
${ }^{1}$ Khairuddin and ${ }^{2}$ Bakhruddin \\ ${ }^{I}$ Department Educational Administration Program University of Syiah Kuala Banda Aceh 23111 \\ ${ }^{2}$ LPMP Trainer of Aceh Province - Indonesia
}

\begin{abstract}
On the Job Learning is one way to improve the capability of principals to their own competence. This research study aims to determine the program, implementation, evaluation and follow-up on the job learning that can improve the competence of principals held by LMP Aceh province. Descriptive method with qualitative approach is used in the present research. The data is collected by observation, interview and documentation. The research subjects is principal. Data processing qualitative analysis research shows that on the job learning can improve the competence of the principal. The research concludes that the implementation of on the job learning on education and training (Diklat) to strengthen the competence of the principal is divided into three stages, i.e. 1) socialization action plan, action plan management, leadership and supervision of creative learning, innovative, critical thinking, problem solving and entrepreneurship. Drafting its done by each participant at the end of training, the first stage under the guidance of a resource, 2) implementation of an action plan by each principal at their schools within maximum of two months under monitoring persons appointed by the training providers, and 3) the preparation of implementation follow-up report by the principal of each school as a participant.
\end{abstract}

Keywords: On-the-job learning, competence, principals

\section{Introduction}

Education and training (Diklat) is a decisive factor in improving the competence and performance of principals in achieving national education goals. Presidential Instruction (Instruksi Presiden) No. 1 (2010), mandates that "Every principal required to attend education and training (Diklat) to strengthen the competence of heads and principals in the provision or the district/city each". However, in the implementation, there are still obstacles faced, among others, the participants have not master in ICT and limited their time to attend the training. Subject matter in Diklat delivered in accordance with National Education Minister Regulation No. 13 (2007) on Standards for principal. There are five dimensions of competence that must be possessed by the principal, i.e. the dimensions of personal competence, managerial, supervision, entrepreneurship, and social. In order to cultivate the competence of principals, it is necessary to strengthen the ability of principals through training programs.

Strengthening the ability of principals through educational programs and training in carrying out their duties and functions as the policy of Minister of National Education is a program that can not be avoided. The general objective of education and training is to improve the competence and performance of principals. Education and training within the Institute for Education Quality Assurance (LPMP) Aceh, focused on improving the competence of principals to manage, lead and supervise teachers in developing learning-based on creativity, innovation, problem solving, critical thinking, and entrepreneurship to produce graduates who have the creativity, innovation and problem-solving skills.

Education and training within the LPMP Aceh in 2010 against 706 people were done in three stage i.e. in service learning 1 , on the job learning and in service learning 2. In more detail, the specific purpose is to develop competence program for principals.

In service learning 1 stage aims to improve the ability of the development of culture education and national character, school-based management, thought leadership, entrepreneurship, academic supervision, Action Research School (PTK), School Self-evaluation and self development to change the mindset, attitudes, and patterns of action in order to make changes, and to provide basic supplies to prepare an action plan (designing the changes that can be made within month). On the job learning training stage aims to change learning through action plan that has been prepared at in service learning 1 stage. While on In service learning 2 training stage intend to reflect and share experiences results from in service learning 1 stage and on the job learning stage among the participants.

The objectives of this study is whether through on the job learning can improve the competence of principals in public high schools located at Banda Aceh.The purpose of this study was to determine: Program on the job learning to improve the competence of principals in public high schools in the city of Banda Aceh, implementation of on the job learning to improve the competence of principals in high schools in the city of 
Banda Aceh, evaluation and follow-up program on the job learning to improve the competence of principals in public high schools in Banda Aceh.

Education and training is an activity to acquire knowledge, intellectual processes and the acquisition of competence. It is broad or focus on a broad, gradual and activities carried out in a relatively long time. Training can be done by school, college and the programs instructed. While training is an activity to increase the skills of individuals based on the work that is being practiced or related work.

Education and training is done at the time of the skills required. Education and training to help employees in understanding a knowledge in its application to improve the skills, attitudes and increase individual motivation in working order of its work satisfactorily. Skills can be done with seminars, workshops, counseling, coaching, mentoring, and so on. Education and training is special which is focuse on one thing only and not staged. Because the nature of the application, then the training is done tends to be the practice in order to achieve organizational goals. Increasing attitude can be done with methods of games that are currently being developed by the training provider. Improved attitude is useful for creating a working environment that is desired and can also increase the motivation of individuals and build teamwork. Every development, education and training have own meaning and its own activities. The development is conducted and training activities for the period ahead.

Education and training, in the context of the broader dimensions of how management training, so that training can run well and managed effectively and efficiently. Strategic management training as a concept can be translated "The process of planning, organizing, mobilizing and evaluation of training activities by utilizing aspects of training to achieve the training objectives effectively and efficiently".

The training that is effective and efficient is the process-oriented training, in which the organization can implement systematic programs to achieve the objectives and outcomes aspired. So that the training institution can produce a good human resources abilities, skills and attitude changes are more independent. Training can affect the competence of principals to achieve the goal of education and teaching in the school.

Thus the training begins with an analysis, the analysis of the needs of the things that will be the object of training, then proceed with the design of the training program, which is a step designing training programs.

The next stage is the implementation and application, the process of implementation and adoption of training programs. Then concludes with an evaluation that is the stage to give an assessment and analysis of the development. At each stage there will be a feedback process, which aims to control the implementation and training process. Planning training is essentially the process of drafting a training program, which is the process of setting up various things about the training preparation. In general, Gomes (2000:204) suggests there are three stages in the training i.e. assessment stage, the implementation stage and the evaluation stage, or with other terms there is the planning phase, the implementation phase and post-training phase.

Randall (2003:323) mention that the main purpose of the training is to eliminate disadvantages to both present and future (anticipated, which could result in employees working below the level desired). Definition of training within the government is more popularly known as education and training. Training in this case relates to building activities and the development of knowledge, skills, techniques, attitudes and experiences.

At the moment, training that is conducted in general there has been no follow up, resulting in less impact on training participants. Therefore LPMP implement education and training primarily for principal gradually in the form of in service learning 1, on the job learning and service learning 2 in order to maximize results. Indonesian Government Regulation (PP) No. 101 (2000) on education and training for Pegawai Negeri Sipil (PNS), stating that in order to establish the figure of PNS as mentioned above, the necessary education and training which leads to: 1) Increase the attitude and spirit of dedication of community-driven, nation, state, and country, 2) Improved technical competence, managerial, or leadership, and 3) Improvement of the spirit of cooperation and responsibility in accordance with the work environment and organization.

The rationale is set out in the Government Regulation are: 1) Education and training is an integral part of the guidance system for PNS, 2) Education and training is linked to the career development of PNS, 3) System education and training includes the identification process needs, planning, implementation, and evaluation of education and training, and 4) education and training geared to preparing for PNS in order to meet the requirements specified positions and needs of the organization, Including procurement cadre of leaders and staff.Thus the training as a process of expanding the awareness and presence of someone being himself. Training has clear goals and objectives so that the participants considered as raw material to be processed in order to be a product that is already planned. This suggests that education and training as a process of humanizing and equip participants with skills that can be used to improve their competence.

In connection with the concept of education and training, Subagio. (2000:42) identifies training as a process of developing talent, skills, and the ability of employees to complete a specific job. While Saleh (2003:34) argues that the training is improving worker perfomance to a particular job which it is responsible. In line with the above concept, Usman (2002:54) defines education as an effort to prepare students through guidance, instruction, and training for its role in the future. While training is an effort to improve the 
performance of employees on the job which it is responsible. Diana (2001:42) assumes the adult learning model andragogy is based on: (1) adults need to know why they have to learn something, (2) adults need guidance itself, (3) adults have a different experience with teenagers, (4) adults learn effectively and satisfactorily when their experience is used in learning, and (5) adults learning focus on a task orientation, problems or life.

Training success is measured through evaluations of coaches, participants, and organizing training. Evaluations are triangulation, i.e. the evaluation of coaches conducted by participants and organizers. The evaluation of the participants conducted by coaches and organizers. Strengthening the ability of principals through competency training program principals in carrying out their duties and functions as the policy of Minister of National Education is a program that can not be avoided. At least three things behind the need to develop a program of strengthening the ability of the principal.

Increased competence of principals can be implemented in various ways one of them through education and training. Because it receives through the practical experience on the job learning is extremely precise. Therefore, it required training undertaken LPMP Province of Nanggroe Aceh Darussalam to conduct field work through on the job learning in the educational unit. To be more effective training can be implemented with the approach that has been affirmed by Baedhowi (2010:6) is "The training is effectively done with the approach in service learning, on service learning and in service learning".

Training of principals held by LPMP Aceh is giving not only the theory but also the practice field through on the job learning at their respective schools. Implementation Guidelines Education and Training (2010:37) asserts that: training of the second stage (on the job learning) is a stage of training is very important in order to strengthen the ability of the principal, because this training competence based principals as defined in Regulation of the Minister of Education national No. 13 (2007). Therefore, the implementation of the second phase of training (on the job learning) should be organized very well.

The purpose of training the second stage (on the job learning) is to facilitate principals to begin implementing all the material in their respective schools, so that the principals do not only have an understanding of all the training materials, but also have the skills to manage, lead, and supervise creative learning, inivatif, critical thinking, problem solving, and entrepreneurial spirit. Through the results of on the job learning, principals have competence in managing, directing, and supervising innovative learning, creative problem solving, and foster entrepreneurial instincts. Principals, who have conducted on the job learning in their school, have the ability to formulate standards of learning process in the school.

On the other hand the principal can formulate the performance of management and how to implement in the school. It have an understanding of supervision and be able to develop a program of academic supervision in order to cultivate the skills of teachers to manage the learning process in innovative, creative and foster an entrepreneurial. It should have skilled to conduct academic supervision using a variety of supervision techniques and to do an action research in the school (PTK) and able to solve problems faced.

Competence means "fitness or ability" which means the skill ability. In Kamus Besar Bahasa Indonesia (KBBI) stated that competence is "the authority to determine something". Thus, the term competence contained "ability". The term of competence is closely related to the possession of knowledge and skills as a teacher. Boediono (2002:23) states that "Competency is defined as the knowledge, skills and values reflected in the basic habits of thought and action". Based on this opinion, means competence refers to the ability to implement something that is acquired through education. Competence showed performance and act rationally to meet certain specifications in carrying out educational tasks. Said to be rational because it has a clear direction and purpose. While performance is the real behavior in the sense of not only observed, but also includes conduct that is far from being invisible.

A principal must fully understand whether it has demonstrated its ability to exhibit attitudes and behaviors that support the principal's personality that is said to be a leader. This basic personal competence will determine its other competencies, especially in implementing education programs of national, province, and district/city. The principal have an additional knowledge in the field of planning and implementation of educational programs, so that it must be able to demonstrate its performance based on policy, planning, and education programs.

Principals should have the knowledge, attitudes and behaviors that rise based on competence principals above, thus it is the basis of knowledge of how performance should be the principal for the right target, although not easy. To assess the performance of the principal related to personal competence with sub competency has a talent and interest in the position as an educational leader, the performance of the principal related to his ability as a school leader. Performance of the principal in the managerial competence also includes the ability in administrative system. So in this case the principal as managers of educational institutions in accordance with the level of education respectively. The confirmation of the existence of a principal as a manager in an educational institution can be judged from the competence to manage institutional, which includes: (1) developing a administration system of the school, (2) develop operational policy of the school; (3) develop a school rule that is related to qualifications, specifications, procedures, guidelines, work instructions, and so on; 
(4) conduct institutional analysis to produce an efficient organizational structure and effective; and (5) developing the organizational units in schools on the basis of the function. The principals competence which are quite central and relating to the sustainability of the school program is entrepreneurial competence. The school is able to realize this entrepreneurial ability then the principals must be able to demonstrate ability in partnership with donors, as well as capable to build an independent school with entrepreneurship efforts. The principal is not only to have a number of competencies, but also has some basic tasks in accordance with the regulations. The key task of the principal at all levels covers three areas, i.e.: (a) managerial duties, (b) supervision, and (c) entrepreneurship. The basic job description is as follows.

Education is a basic capital in improving human resources. One of the goals of education is to prepare a person to be able and skilled in a field of work. Education is the most important requirement for holding a certain position in the works. This is due to the educational background will reflect intelligence and specific sklil as a predictor of the success of one's work. Ali (2001:47) states that "education is an effort to provide information and skills which can realize desires, needs and individual competencies in order to achieve personal and social lifestyles satisfactory". Syah (2006:53) states "education is a thing absolute is to humanize human beings to human culture".

Djamariah (2004:81) asserts that "there is a positive relationship between level of education and level of competence and mastery of subject matter". While Roestiyah (2000:21) mentions that "the higher the level of education will be the more likely to succeed in its work". This positive relationship between level of education and competence of the principal of its performance. By doing certain activities one can do certain effort, as well as learn from the experience of learning activities are carried out repeatedly so that it will be able to improve their knowledge and skills, so as to be able to make a person more quality in their duties. Sudjana (1989:34) states that to work, people gain experience and knowledge to create an understanding of the objects, the arguments and theories are useful to achieve the goal.

Experience also affect the competence of the principals. Ali (2001:52) mentions that "the knowledge gained through experience, innate talent is a certainty to thrive." Principal will have a lot of experience by solving the problems faced by principals and teachers in schools. This is consistent with the statement Sumantri (2002:32) that the principal with long period to lead the school will have an experienced and accustomed to face and solve problems. In realizing increased competence principals, it is necessary should be coaching principals by all relevant parties, such as that done by LPMP through in service learning 1, on the job learning, and in service learning 2. Training is successful if implemented in phases, in fact at this moment, training conducted by LPMP province of Aceh has not been as it should be. Therefore training to increase the competency of the principals is indispensable.In addition to seeing the effectiveness of the training undertaken by LPMP Aceh province on competence development principals in the province of Aceh.

The successful of an organization in reaching a goal depends on how the existing personnel carrying out the work in accordance with the duties and responsibilities of each. It is called with the performance of personnel within the organization. Whether good or not the personnel performance is determined by how the ability and willingness fortified with the knowledge, attitudes, skills, motivation and external factors in carrying out its duties and responsibilities. External factors referred as proposed by Anoraga (2005:56), i.e. "the work was interesting, good wages, good security and job protection, appreciate the meaning of the work carried, a conducive working atmosphere, a clear promotion system and career, feel involved in any activities of the organization, there is attention to matters of personal, leadership attention to subordinates and high work discipline".

Training is effective when implemented in phases i.e. in service, on service and back to in service, in fact during this training conducted by various parties has not been as it should be. Therefore LPMP Aceh province in any training undertaken to increase the competence of principals is done in three stages, the in service learning 1 , on the job learning and in service learning 2 . In the second phase of the training program (on the job learning), all participants (principals) are assigned practice applying learning leadership, academic supervision, and the values of entrepreneurship in their respective schools during the first month. All activities are practiced and implemented to be made in the form of a report to be submitted at in service learning 2 stage.

\section{Methodology}

In pursuit of the research, methods and approaches is a key performance. The method used in this research is descriptive method. Alsa (2004:29) reveals that qualitative research assume that "humans are active, who have freedom will, whose behavior can only be understood in the context of a culture whose behavior is not based on the law of cause and effect".

Qualitative researchers will put his attention to understand the behavior, views, perceptions, attitudes and others based on the views studied subject in which they live and ordinary activities. Descriptive method more precise used to answer the problems in the study, with appropriate consideration to the situation and 
circumstances. Descriptive research is research that seeks a symptom and events and become the focus of attention for being recognized as the material to be poured and described in the report.

Subjects of the research were people, sources or informants who can provide information or data to researchers. Determining the subject of this study conducted purporsive. It is based on the characteristics of the subject matter is purposive, namely (1) the design of the research subjects that arise can not be determined in advance; (2) determination of the subject in sequence; (3) continuous adjustment of the subject, and (4) the election ended if there has been a repetition

Therefore the subject of this study are all principal of public High School in Banda Aceh who have trained reinforcement principals held by LPMP Aceh province as many as 14 peoples. Data collection techniques used were observation, interviews and documentation. Data analysis technique used in this study is qualitative analysis aims to compile the data to be interpreted.

\section{Result And Discussion}

Of the many programs and activities that have been implemented by LPMP Aceh Province in accordance with the duties that have been mandated by the Ministerial Regulation (Permendiknas) No. 7 (2007), aims to improve the competence and the professionalism of principals that can ultimately improve the quality of education nationwide.

One program targeted and reaches directly to the professionalization of the principal in accordance with Presidential Instruction (Instruksi Presiden) No. 1 (2010) is through education and training. LPMP Aceh province to implement education and training to strengthen the competence of principals in three phases that aims to strengthen the ability of the principal that is focused on improving the competence of principals manage, lead and supervise teachers in developing learning-based creativity, innovation, problem solving, critical thinking, so as to produce graduates who have the creativity, innovation, problem-solving skills and entrepreneurial instinct.

The general objective of this training is to strengthen the ability of principals through competency development training that is focused on improving the competencies of school principals in managing, directing, and supervising teachers to develop lessons based on creativity, innovation and able to solve the problem. In more detail, special-purpose programs of in service learning 1 stage is to improve the ability of the development of cultural education and the character of the nation, school-based management, thought leadership, entrepreneurship, academic supervision, Action Research School (PTK), and self-development, to change the mindset, attitudes, and patterns of action, to provide a basis attitude for preparing an action plan (designing the changes that can be made for 1 month).

Implementation of the second phase of training (on the job learning) is a very important stage in order to strengthen the ability of the principal, because this training is competency-based principal as outlined in the National Education Minister Regulation No. 13 (2007). Therefore it should be organized as well as possible.

The purpose of the second stage (on the job learning) is to facilitate trainees (principals) to begin implementing all the material in their respective schools, so that trainees do not only have an understanding of all the training materials, but also have the skills to manage, lead, and supervise creative learning, inivatif, critical thinking, problem solving, and entrepreneurial spirit.

To reflect and share experiences the results in service learning 1 stage and on the job learning stage among the participants in a service learning 2. At the end of this training all participants are expected to have the competence of the principal as outlined in the National Education Minister Regulation No. 13 Year 2007 on Standards for School, especially the competencies of school principals in managing, directing, and supervising teachers to develop lessons based on creativity, innovation, problem solving, critical thinking, and values of entrepreneurship.

Interviews with several principals in Banda Aceh against on the job learning stage in the training conducted by LPMP is done very effective. This is due to different patterns of training with the training conducted by the agency or another NGO, for training conducted by LPMP divided into three phases to improve the competence and performance of school principals in fostering sekaolah auxiliaries.

Interviews with the principals of public high schools in Banda Aceh obtained information that the education and training within the LPMP Aceh province is done in three phases: the first in service learning 1 for 5 days in 40 hours of, the second phase on the job learning for 1 month as many as 88 hours and the third phase in service learning 2 for 3 days as much as 20 hours. The total amount of 148 hours with the most hours of lessons on the on the job learning in each school.

In addition to these programs in the above table, the heads of high schools in Banda Aceh suggests that the material received at first in service is (1) the development of the nation's culture and character education; (2) school-based management; (3) instructional leadership; (4) the academic supervision; (5) entrepreneurship in improving the quality of learning; and (6) research school action. 
Most heads of high schools in Banda Aceh confirms that the material obtained in the in service learning 1 is very helpful in carrying out its duties and functions in their respective schools. In addition they also recognize that education and training can increase the LPMP implemented fifth competence as a principal. Generally principal high schools in Banda Aceh confirms that through on-the-job learning can improve their competence in both school-based management, thought leadership, academic supervision, entrepreneurship and research school action.

Interviews with several principals obtained information that through on-the-job learning can enhance the competence for each of the results of activities undertaken during the first months should be presented on in service learning 2 to decide whether or not to pass the training.It can be concluded that, on the job learning programs implemented during one month by the school after participating in service learning 1 training for 5 days, this program needs to be preserved and passed in order the principal competence as the first person in the educational unit can be increased. Because during an on-the-job learning the principal of high schools in Banda Aceh formulate an action plan on school self-evaluation using the instruments that has been agreed then made a report. the principal develop a program and have a clear supervision schedule then prepared a report on the results of supervision, as well as conduct research school action (PTK) appropriate pre-defined format.

Results of interviews with principal of high schools in Banda Aceh and the document data show that activity on the job learning is implemented in each school principals within 1 (one) month. In this second phase of training, each of the principal as a trainee assigned to practice implementing the first phase of the overall training material, in the form of making follow-up plan drawn up at the end of the first phase of training.

The interview result and documentary data obtained information tasks assigned facilitator to the participants of the training in this case the principal of the public high schools in the city of Banda Aceh in accordance with LKKS-7.4 are: 1) initiate activity action plan in the stage of on the job learning, do school evaluation with using instruments self evaluation school agreed, 2) make a report on the school self-evaluation accordance with the format, 3 ) ended the activities of the action plan in the stage of on the job learning, also did back in school evaluation using instruments self evaluation schools that have agreed, 4) make school selfevaluation report in accordance with the format. Choose one of the national education standards (SNP) associated with the Content Standards or Process Standards or Standards Management, and 5) the entire report will be submitted to the facilitator at the stage of in service learning 2 at LPMP Aceh province.

Thus the principals, in order to strengthen the ability implemented based on competencies that must be owned by each participant after they attend a training program, will be able to do something. Curriculum, implementation, and evaluation, as well as strengthening the certification must refer to the competencies required and needed by the trainees to enable them to carry out their duties and functions. To embody the on the job learning, the principal of the school is equipped with teaching materials from the stage of in service learning 1, i.e. 1) regulation of strengten the principal competence, 2) the development of the nation's culture and character education; 3) school-based management, 4) leadership learning, 5) academic supervision, 6) entrepreneurship, 7) self-development, 8) action research school (PTK), 9) guidelines for the preparation of an action plan and sheet action plan, 10) guidelines and Instruments mapping principals and 11) school selfevaluation

The teaching materials can be developed further by the training provider. A variety of learning resources that can be accessed by resource persons and trainees, either through electronic learning resources, writing (books, journals, magazines), people, work, and even from various mass media, both electronic and written. It is important to be underlined that strengthening participants into broad horizons with the introduction of learning resources are so numerous and rich in information, knowledge, and science.

In the second phase of the training program (on the job learning) all of the principal as the training participants were assigned to practice applying learning leadership, academic supervision, and the values of entrepreneurship in their respective schools in accordance with the pattern or work lembara principal.

Program implementation on the job learning indicates that the execution phase on the job learning on training to strengthen the competence of the principal of the school is divided into three stages, i.e. 1) socialization action plan, action plan management, leadership and supervision of creative learning, innovative, critical thinking, problem solving and entrepreneurship. Drafting its done by each participant at the end of training, the first stage under the guidance of a resource, 2) implementation of an action plan by each principal at their schools within maximum of two months under monitoring persons appointed by the training providers, and 3) the preparation of implementation follow-up report by the principal of each school as a participant.

Training to strengthen the ability of principals through training programs competence of the principal in carrying out their duties and functions as the policy of the Minister of National Education is a program that can not be avoided and are not carried away, should be followed up by an evaluation using instruments that have been established in each stage.

Results of interviews with principal of high schools in Banda Aceh obtained that all activities performed by the principal in the stage on the job learning in the respective schools according to school 
principals worksheet that has been prepared by the resourch and organizers. Most principals affirming when the report is not in accordance with the format that has been provided or action research report the same to the others, then the participant is declared not feasible, so the certificate has not been given to him.

To be eligible a principal in the principal reinforcement training if they have completed all their duties in accordance with the work sheet principal that have been confirmed as well on the duty at stage in service learning 1 , on the job learning and in service learning 2. It can be concluded that the evaluation and follow-up of programs on the job learning through the reports of the principal as the training participants on in service learning a second after the on-the-job learning lasts for one month, namely 1) a report on school self-evaluation using instruments that have been set, 2) report the results academic supervision that has been done, 3) presentation on classroom action research (PTK), and 4) reflection through the third assessment and interviews about the report mention above.

\section{Conclusion}

On the job learning programs, which is implemented during one month by the school after participating in service learning training on the first 5 days, needs to be preserved and passed in order to increase principal competence. Because during an on-the-job learning, the principals of high schools in Banda Aceh formulate an action plan on school self-evaluation using Self Evaluation School instruments that has been agreed. The principals should also formulate the development of programs and supervision schedule clear and prepared a report on the results of supervision, as well as conduct research school action appropriate pre-defined format.

The pattern of implementation on the job learning program is divided into three stages, namely: 1) socialization action plan, action plan management, leadership and supervision of creative learning, innovative, critical thinking, problem solving and entrepreneurship. Drafting its done by each participant at the end of training, the first stage under the guidance of a resource, 2) implementation of an action plan by each principal at their schools within maximum of two months under monitoring persons appointed by the training providers, and 3) the preparation of implementation follow-up report by the principal of each school as a participant.

Evaluation and follow-up of programs on the job learning through the reports of the principal as the training participants on in service learning 2 after the on-the-job learning lasts for one month, i.e.: 1) a report on school self-evaluation using instruments that have been set, 2) report the results academic supervision that has been done, 3) presentation on classroom action research (PTK), and 4) reflection through the third assessment and interviews about the report mention above.

\section{Acknowledgements}

This paper was carried out using joint research my department program with LPMP program of Aceh Province, thanks for support and encouragement. The author would like to thank profusely my friends in education department program that helped in the process of retrieval and data processing.

\section{References}

[1]. Amiruddin, (2006). Manajemen Pendidikan Berbasis Sekolah, Quantum Teaching Ciputat.

[2]. Abdul Majid.(2008).Perencanaan Pembelajaran Mengembangkan Standar Kompetensi Guru,Bandung, PT.Remaja Rosdakarya Offset.

[3]. Beodhowi,(2010).Petunjuk Teknis Tentang Pelaksanaan Pendidikan dan Pelatihan Kepala Sekolah, Jakarta: PT Aksara Agung

[4]. Harun Cut Zahri Harun (2009).Manajemen Sumber Daya Pendidikan, Pena Persada Desktop Plubliser Yokyakarta.

[5]. Depdiknas (2008). Penilaian Kinerja Sekolah, Direktorat Tenaga Kependidikan, Dirjen PMPTK.

[6]. Depdiknas. (2006). Undang-Undang RI Nomor 14 Tahun 2005 tentang Guru dan Dosen. Jakarta: PB. PGRI.

[7]. Depdiknas (2007).Manajemen Sekolah, Pusat Pendidikan dan Pelatihan Pegawai, Sawangan Depok.

[8]. Pupuh Fathurrohman, Sobry Sutikno (2007).Strategi Belajar Mengajar. Bandung:PT.Refika Aditama. 